\title{
Reduction of incidence and mortality of respiratory distress syndrome by administration of hydrocortisone to mother
}

\author{
SVETOZÁR DLUHOLUCKÝ, JOZEF BABIC, and IVAN TAUFER \\ From the Departments of Obstetrics and Gynaecology and Paediatrics, Newborn Intensive Care Unit, \\ Regional Hospital, Banská Bystrica, Czechoslovakia
}

\begin{abstract}
Dluholucký, S., Babic, J., and Taufer, I. (1976). Archives of Disease in Childhood, 51, 420. Reduction of incidence and mortality of respiratory distress syndrome by administration of hydrocortisone to mother. Hydrocortisone (100 $\mathrm{mg}$ in a single injection) was given to 120 pregnant women with threatened premature delivery. None was given to a control group of $\mathbf{4 0}$ mothers. Orciprenaline was also given to all the mothers to inhibit uterine activity. The administration of hydrocortisone did not accelerate delivery and in the treated group 55 babies were eventually born at term; none died or had perinatal complications. 65 babies were born prematurely, and yielded these conclusions: if the mother received hydrocortisone less than 24 hours before delivery it had little or no influence on the incidence of and mortality from the respiratory distress syndrome (RDS). If birth occurred more than 24 hours after hydrocortisone injection, the incidence and mortality from RDS were lowered. Prolonged rupture of membranes had no effect on the mortality rate from RDS. It was concluded that hydrocortisone administered to mothers with threatened delivery is an effective means of mitigating the incidence and severity of RDS in infants.
\end{abstract}

The important role of surfactant deficiency in the respiratory distress syndrome (RDS) is well accepted (Avery and Mead, 1959; Gluck and Kulovich, 1973a; Rorman, 1973). Works with animals led to the conclusion that an increased level of glucocorticoid in fetal blood accelerates lung maturation (Kotas and Avery, 1971; Chiswick, et al., 1973).

Certain stresses have also been thought to increase the production of surfactant. For example, Kotas, (1973) showed that in the fetal rabbit intraperitoneal injection of Staphylococcus aureus caused accelerated maturation of the lung. In man, premature rupture of the membranes (Yoon and Harper, 1973; Bauer et al., 1974) and antenatal infection (Gluck and Kulovich, 1973b) have been associated with a lower than expected incidence of RDS, though Jones et al., (1975) found no such effect. Such stresses may cause fetal glucocorticoids to rise and surfactant synthesis to increase. On the other

Received 17 September 1975. hand, postnatal administration of glucocorticoids has no favourable effect (Baden et al., 1972).

Liggins and Howie (1972) first reported the use of betamethasone in 282 mothers in whom premature delivery threatened or was planned before 37 weeks' gestation; RDS occurred less often in the babies of treated mothers (9\%) than in controls (25.8\%). Fargier et al. (1974) published similar results. However, there are unfavourable side effects from the antenatal use of glucocorticoids. In sheep they may induce preterm delivery (Liggins, 1969). Methylprednisolone does not affect lung maturation but does induce labour (Tauesch, Avery, and Sugg, 1972).

We have sought to determine whether administering hydrocortisone to a woman in premature labour (1) is as safe and effective as betamethasone; (2) accelerates delivery; (3) decreases the incidence of RDS; (4) needs to be given at least 24 hours before delivery in order to be effective; (5) produces differences in acid-base balance and in mortality between a treated and an untreated control sample. 


\section{Reduction of incidence and mortality of respiratory distress syndrome}

\section{Material and method}

The study was carried out over a period of 21 months, from January 1973 to September 1974. Of 160 mothers admitted to hospital because of threatened premature delivery, hydrocortisone was given to 120 while a control group of 40 received none. Gestational age was 37 weeks or less. Treated and control subjects were chosen at random. A single intramuscular injection of $100 \mathrm{mg}$ hydrocortisone was given to the treated group. To inhibit uterine activity we used a preparation of orciprenaline (Alupent, Boehringer), $0.5 \mathrm{mg}$ in an infusion of $400 \mathrm{ml} 5 \%$ dextrose at a rate of $1 \cdot 5-10$ $\mu \mathrm{g} / \mathrm{min}$ (Babic et al., 1974; Baillie, Meehan, and Tyack, 1970; Di Terlizzi, 1973).

When the infant was delivered the umbilical cord was tied and sodium bicarbonate $(4 \cdot 2 \%$ solution, $2 \cdot 5$ $\mathrm{mEq} / \mathrm{kg}$ with dextrose) was given via the umbilical vein in order to treat any postnatal acidosis. The Apgar score was recorded and the infant was moved to the intensive care unit of the paediatric department, where its condition was further recorded (maturity, Silverman score, acid-base balance), and the gestational age was estimated from the date of mother's last menstrual period, and the clinical and neurological status.

The diagnosis of RDS was made on the clinical findings (Silverman score), the acid-base balance, and in the case of deceased infants by lung histology. Depending on the severity of disease, infants were treated with bicarbonate and oxygen, the temperature maintained in an incubator, while severe cases were treated with continuous positive airway pressure using Gregory's box, or by intermittent positive pressure breathing by Bird respirator Mark 8. These infants received a $10 \%$ solution of dextrose together with fresh frozen plasma via an umbilical vein catheter or via a peripheral vein by using an infusion pump.
Of the 120 mothers admitted with threatened premature labour, in 55 after oxciprenaline therapy pregnancy continued to term, with delivery of 55 term infants. The remaining 65 mothers delivered 65 preterm infants. This sample was divided into two groups (Table I). In group C (31 mothers) the hydrocortisone was given $>24$ hours before delivery, in group B (24 mothers) it was given $<24$ hours before delivery (mean $12 \cdot 4$, range \pm 8 hours). Group $A$ (40 mothers) did not receive hydrocortisone and served as a control. There was no difference between the 3 groups as to sex, weight, gestational age, method of delivery, or treatment after delivery. There were no stillbirths.

In order to evaluate the influence of premature rupture of membranes on the mortality rate from RDS we studied retrospectively all preterm deliveries during the previous 3 years. This group consisted of 308 preterm infants, which included the groups $A, B, C$. In 88 of the deliveries the membranes had ruptured after the onset of labour.

\section{Results}

Children born at term of mothers who had received hydrocortisone. There were 55 such mothers and these delivered 55 infants at term. The average birthweight of the infants was $3 \cdot 128 \mathrm{~g}$ and gestational age was 38.6 weeks; they had no perinatal complications, and none died. All were discharged from hospital after the normal 5 days.

Incidence of RDS in infants born preterm of mothers who had received hydrocortisone. The incidence and mortality from RDS are given in Table II. The incidence of RDS was $45 \%$ in

TABLE I

Preterm infants delivered from 65 hydrocortisone-treated and 40 untreated mothers

\begin{tabular}{|c|c|c|c|c|}
\hline Group & $\mathbf{n}$ & $\operatorname{Sex} M / F$ & Birthweight (g) (mean \pm SE) & Gestational age $(w)($ mean $\pm S E)$ \\
\hline $\begin{array}{l}\text { A } \\
\mathbf{B} \\
\mathbf{C}\end{array}$ & $\begin{array}{l}40 \\
34 \\
31\end{array}$ & $\begin{array}{l}15 / 25 \\
13 / 21 \\
17 / 14\end{array}$ & $\begin{array}{l}1682 \cdot 4 \pm 494 \cdot 6 \\
1579 \cdot 7 \pm 548 \cdot 3 \\
1671 \cdot 8 \pm 788 \cdot 7\end{array}$ & $\begin{array}{l}31 \cdot 3 \pm 3 \cdot 4 \\
31 \cdot 6 \pm 3 \cdot 8 \\
31 \cdot 4 \pm 2 \cdot 7\end{array}$ \\
\hline
\end{tabular}

Group A, Untreated controls.

Group B, Treated $<24$ hours before delivery.

Group C, Treated $>24$ hours before delivery.

TABLE II

Incidence and mortality of $R D S$

\begin{tabular}{|c|c|c|c|c|c|}
\hline \multirow[t]{2}{*}{ Group $\star$} & \multirow[t]{2}{*}{$\mathbf{n}$} & \multicolumn{2}{|c|}{ Incidence of RDS } & \multicolumn{2}{|c|}{ Mortality in RDS } \\
\hline & & Cases & $\%$ & Cases & $\%$ \\
\hline $\begin{array}{l}\text { A } \\
\mathbf{B} \\
\mathbf{C}\end{array}$ & $\begin{array}{l}40 \\
34 \\
31\end{array}$ & $\begin{array}{r}18 \\
11 \\
5\end{array}$ & $\begin{array}{l}45 \\
32 \\
16\end{array}$ & $\begin{array}{r}14 \\
8 \\
3\end{array}$ & $\begin{array}{r}35 \\
23 \\
9 \cdot 7\end{array}$ \\
\hline
\end{tabular}

$\star$ See Table I. 
group A, $32 \%$ in group B, and $16 \%$ in group C. The difference between groups $A$ and $C$ was significant $(P<001)^{\star}$ but not between groups $A$ and $B$, or $B$ and $C$. The mortality from RDS was $35 \%$ in group $A, 23 \%$ in group $B$, and $9.7 \%$ in group 3, the difference between groups $\mathrm{A}$ and $\mathrm{C}$ being significant $(\mathrm{P}<0.05)^{\star} . \quad p \mathrm{H}$ and $\mathrm{PCO}_{2}$ values are shown in Table III. $p \mathrm{H}$ values were

\section{TABLE III}

Mean values and range of $\mathrm{pH}$ and $\mathrm{PCO}_{2}$ in infants

\begin{tabular}{c|c|c|c}
\hline Group & $\mathbf{n}$ & $\mathrm{pH}$ & $\mathrm{PcO}_{2}(\mathrm{mmHg})$ \\
\hline A & 38 & $7 \cdot 259 \pm 0 \cdot 158$ & $61 \cdot 3 \pm 31 \cdot 1$ \\
B & 31 & $7 \cdot 283 \pm 0 \cdot 158$ & $56 \cdot 6 \pm 31 \cdot 2$ \\
C & 29 & $7 \cdot 302 \pm 0 \cdot 240$ & $52 \cdot 0 \pm 21 \cdot 4$ \\
\hline
\end{tabular}

Statistical signficance (Student's ' $t$ ' test)

\begin{tabular}{c|c|c}
\hline Groups & pH & $\mathrm{PcO}_{2}$ \\
\hline $\mathrm{A}: \mathrm{B}$ & $\mathrm{P}<0.05$ & $\mathrm{NS}$ \\
$\mathrm{B}: \mathrm{C}$ & $\mathrm{P}<0.01$ \\
$\mathrm{~A}: \mathrm{C}$ & $\mathrm{P}<0.001$ & $\mathrm{NS}$ \\
& & NS \\
\hline
\end{tabular}

^See Table I.

significantly different among all 3 groups. There was no statistical difference in $\mathrm{PCO}_{2}$ values, though those in group $C$ were lower than in groups $A$ and $B$.

Effect of premature rupture of membranes on mortality from RDS. Table IV summarizes results which show that premature rupture of membranes had no significant effect on the mortality rate from RDS (cases lacking histological verification of hyaline membrane disease were excluded).

TABLE IV

Prolonged rupture of membranes and mortality from $R D S$

\begin{tabular}{l|c|c}
\hline \multicolumn{1}{c|}{ Group } & $\mathbf{n}$ & RDS deaths \\
\cline { 2 - 3 } $\begin{array}{l}\text { Prolonged rupture } \\
\text { Control }\end{array}$ & 88 & $24(27 \%)$ \\
\hline
\end{tabular}

\section{Discussion}

Our results are similar to those of Liggins and Howie (1972) and Fargier et al., (1974), and show that a single injection of $100 \mathrm{mg}$ hydrocortisone had practically the same effect as betamethasone. Previous authors have thought that in man hydro-

$\star$ Pearson's $\chi^{2}$ test. cortisone does not cross the placenta (Liggins, 1969; Motoyama et al., 1971), and hence it has not been used in clinical practice. Our results suggest that it does cross the placenta and is effective in speeding lung maturation.

Our treated groups had a lower birthweight and gestational age than those reported by Liggins and Fargier et al. Perhaps this is why our treatment did not cause as great a reduction of incidence and mortality, while betamethasone may also be more effective. As with betamethasone, the effect of hydrocortisone is greatest when it is given at least 24 hours before delivery. Hydrocortisone did not appear to accelerate delivery since 55 mothers with threatened premature delivery who received it delivered at term.

Although Carson, Tauesch and Avery, (1973) reported that hydrocortisone inhibited division of lung cell in rabbit, Kotas, Mims, and Hart (1974) showed such inhibition to be transient, and to be more than compensated by the advantages of a mature lung at birth.

We have concluded that (1) hydrocortisone given to the mother did not accelerate delivery; (2) hydrocortisone must be given to the mother with threatened premature delivery earlier than 24 hours before delivery in order to be effective. The incidence and mortality of RDS will then be about one-quarter that in infants born to mothers who have not received hydrocortisone. (3) Prolonged rupture of fetal membranes has no favourable effect on mortality rate from RDS.

We thank Dr. J. Scholtz, Chief of the Department of Obstetrics and Gynaecology, Regional Hospital, Banská Bystrica, for encouragement.

\section{REFERENCES}

Avery, M. E., and Mead, J. (1959). Surface properties in relation to atelectasis and hyaline membrane disease. American Fournal of Diseases of Children, 97, 517.

Babic, J., Taufer, I., and Scholtz, J. (1974). Využitie Alupentu v prevencii a liečbe preděasných pórodov. Ceskoslovenská gynekologie, 39, 336.

Baden, M., Bauer, C. R., Colle, E., Klein, G., Tauesch, H. W., Jr., and Stern, L. (1972). A controlled trial of hydrocortisone therapy in infants with respiratory distress syndrome. Pediatrics, 50, 526.

Baillie, P., Meehan, F. P., and Tyack, A. J. (1970). Treatment of premature labour with orciprenaline. British Medical fournal, $4,154$.

Bauer, C. R., Stern, L., and Colle, E. (1974). Prolonged rupture of membranes associated with decreased incidence of respiratory distress syndrome. Pediatrics, 53, 7.

Carson, S. H., Tauesch, H. W., Jr., and Avery, M. E. (1973). Inhibition of lung cell division after hydrocortisone injection into fetal rabbits. Fournal of Applied Physiology, 34, 660.

Chiswick, M. L., Ahmed, A., Jack, P. M. B., and Milner, R. D. G. (1973). Control of fetal lung development in the rabbit. Archives of Disease in Childhood, 48, 709.

Di Terlizzi, G. (1973). L' uso dell' Alupent in ostetricia. Minerva Ginecologica, 25, 225. 
Fargier, P., Salle, B., Baud, M., Gagnaire, J. C., Arnaud, P., and Magnin, P. (1974). Prévention du syndrome de détresse respiratoire chez le prématuré. La Nouvelle Presse Médicale, 3, 1595.

Forman, D. T. (1973). Biochemical basis of hyaline membrane disease. Annals of Clinical and Laboratory Sciences, 3, 242.

Gluck, L., and Kulovich, M. V. (1973a). Fetal lung development. Pediatric Clinics of North America, 20, 367.

Gluck, L., and Kulovich, M. V. (1973b). Lecithin/sphingomyelin ratios in amniotic fluid in normal and abnormal pregnancy. American Fournal of Obstetrics and Gynecology, 115, 539.

Jones, M. D., Jr., Burd, L. I., Bowes, W. A., Jr., Battaglia, F. C., and Lubchenco, L. O. (1975). Failure of association of premature rupture of membranes with respiratory distress syndrome. New England Fournal of Medicine, 292, 1253.

Kotas, R. V. (1973). Accelerated pulmonary surfactant after intrauterine infection in the fetal rabbit. Pediatrics, 51, 655.

Kotas, R. V., and Avery, M. E. (1971). Accelerated appearance of pulmonary surfactant in the fetal rabbit. Fournal of Applied Physiology. 30, 358.

Kotas, R. V., Mims, L. C., and Hart, L. K. (1974). Reversible inhibition of lung cell number after glucocorticoid injection into fetal rabbits to enhance surfactant appearance. Pediatrics, $53,358$.
Liggins, G. C. (1969). Premature delivery of foetal lambs infused with glucocorticoids. Fournal of Endocrinology, 45, 515.

Liggins, G. C., and Howie, R. N. (1972). A controlled trial of antepartum glucocorticoid treatment for prevention of the respiratory distress syndrome in premature infants. Pediatrics, $50,515$.

Motoyama, E. K., Orzalesi, M. M., Kikkawa, Y., Kaibara, M., Wu. B., Zigas, C. J., and Cook, C. D. (1971). Effect of cortisol on the maturation of fetal rabbit lungs. Pediatrics, 48, 547.

Tauesch, H. W., Jr., Avery, M. E., and Sugg, J. (1972). Premature delivery without accelerated lung development in fetal lambs treated with long-acting methylprednisolone. Biology of the Neonate, 20, 85.

Yoon, J. J., and Harper, R. G. (1973). Observations on the relationship between duration of rupture of the membranes and the development of idiopathic respiratory distress syndrome. Pediatrics, 52, 161.

Correspondence to Dr. S. Dluholucký, Dept. of Paediatrics, Regional Hospital, 97416 Banská Bystrica, Czechoslovakia. 